Zeszyty Naukowe Szkoły Głównej Gospodarstwa Wiejskiego

Ekonomika i Organizacja Gospodarki Żywnościowej nr 108, 2014: 45-54

\title{
Piotr Gołasa
}

Katedra Polityki Europejskiej, Finansów Publicznych i Marketingu

Szkoła Główna Gospodarstwa Wiejskiego w Warszawie

\section{Znaczenie kosztów energii w zależności od typu gospodarstw rolnych ${ }^{1}$}

\section{Wstęp}

We współczesnej gospodarce coraz większe znaczenie odgrywają zagadnienia związane z zużyciem energii i efektywnością energetyczną. Ma to kilka podstaw. Pierwszą z nich są kwestie środowiskowe. Udział odnawialnych źródeł energii w Unii Europejskiej wynosi zaledwie $12,5 \%^{2}$, więc każde jej użycie skutkuje spaleniem paliw kopalnych. Prowadzi to do wzrostu poziomu $\mathrm{CO}_{2}$ $\mathrm{w}$ atmosferze. Zgodnie z najnowszym raportem Intergovernmental Panel on Climate Change, to właśnie antropogeniczna emisja $\mathrm{CO}_{2}$ z 95-procentowym prawdopodobieństwem jest przyczyną zachodzącym zmian klimatycznych i będzie prowadziła do wzrostu średniego poziomu temperatury i intensyfikacji nagłych, niekorzystnych zjawisk pogodowych [IPCC 2013]. Drugi powód jest również znaczący. Chodzi o koncepcje Peak Oil (szczytu wydobycia), która powstała w latach 50 . XX wieku. Zakłada, że wydobycie ropy metodami konwencjonalnymi osiagnie w pewnym momencie maksimum, a następnie zacznie stopniowo spadać. Przewidywania te sprawdziły się co do USA, gdzie Peak Oil osiagnięto w 1971 roku [Bowden 1985]. Badania prowadzone w kolejnych latach dotyczące globalnego wydobycia podawały niezwykle rozbieżne daty osiagnięcia tego punktu: od 2017 roku do określenia „nie wcześniej niż 2035" [Chapman 2014]. Pojawiają się również głosy, iż teorie Peak Oil należy porzucić ze względu na to, że ignoruje ona postęp technologiczny, pozwala-

\footnotetext{
${ }^{1}$ Badania finansowe w ramach projektu NCN ,Ekonomiczne uwarunkowania produkcji bioenergii w gospodarstwach rolnych”. Umowa UMO-2011/01/B/HS4/06220.

2 European Environment Agency, http://www.eea.europa.eu/data-and-maps (data dostępu: 15.03.2014).
} 
jący na korzystanie $\mathrm{z}$ do tej pory niedostępnych źródeł, tzw. tight oil, łupków roponośnych czy też ropy wydobywanej z dna morskiego z dużych głębokości [Maugeri 2012]. Jednakże jeden fakt jest niezaprzeczalny - wzrost cen ropy naftowej. Od 2005 roku cena baryłki ropy brent wzrosła z 52 do 107 dolarów w 2014 roku. W tym czasie również wzrastało ogólne zużycie energii na całym świecie, które do 2035 roku ma wzrosnąc o jedną trzecią ${ }^{3}$. Te wszystkie sprawy powodują, że coraz większego znaczenia nabiera kwestia zużycia energii w rolnictwie oraz jej kosztów. Jest to jednak skomplikowane zagadnienie. W przeprowadzonych badaniach stwierdzono, że trudno odnaleźć zależność pomiędzy wartością bezpośrednich nakładów energii w rolnictwie a wartością produkcji, gdyż istnieje tutaj wiele innych czynników, takich jak zmienność pogody, wzrost cen poszczególnych nośników energii czy zmiany technologii produkcji [Pawlak 2012].

\section{Cel i metody}

Celem badawczym artykułu jest określenie wielkości kosztów energii ponoszonych przez polskie indywidualne gospodarstwa rolne i ich udziału w kosztach ogólnych w zależności od typu gospodarstwa.

Do obliczeń wykorzystano dane dotyczące indywidualnych gospodarstw rolnych pozyskiwanych przez Instytut Ekonomiki Rolnictwa i Gospodarki Żywnościowej - Państwowy Instytut Badawczy w ramach systemu FADN (Farm Accountancy Data Network) za lata 2007-2012. W polu obserwacji FADN znajdują się gospodarstwa towarowe. Minimalna wielkość ekonomiczna, po przekroczeniu której włącza się gospodarstwo rolne do pola obserwacji FADN, ustalana jest od 2010 roku obrachunkowego na podstawie analizy sum standardowej produkcji (SO). Jest to uśredniona z pięciu lat wartość produkcji z określonej działalności rolniczej uzyskanej z 1 ha lub od 1 zwierzęcia [FADN 2013]. W praktyce prowadzony jest rachunek polegający na obliczeniu skumulowanej sumy SO z poszczególnych klas, zaczynając od największej, aż do osiagnięcia ok. 90\% SO z populacji badawczej. Dolna granica przedziału, w którym to nastąpi, jest minimalnym progiem wielkości ekonomicznej. W 2012 roku wyniki obliczono dla 10909 gospodarstw o wielkości ekonomicznej większej lub równej 4000 euro.

Typ rolniczy gospodarstwa rolnego określany jest na podstawie udziału poszczególnych działalności rolniczych w tworzeniu całej produkcji standardowej

\footnotetext{
${ }^{3}$ International Energy Agency 2012: World Energy Outlook 2012, Synthesis, Paris.
} 
gospodarstwa. W zależności od pożądanego stopnia szczegółowości badań typy rolnicze można przedstawić na trzech płaszczyznach:

- 8 typów ogólnych,

- 21 typów podstawowych,

- 61 typów szczegółowych.

Na potrzeby pracy przyjęto pierwszy z podziałów. Obliczenia dokonano według rachunku wyników obowiązujących w systemie FADN (tab. 1).

Tabela 1

Grupowanie gospodarstw rolnych według typów rolniczych

\begin{tabular}{|c|c|c|c|}
\hline \multicolumn{2}{|c|}{ Typy rolnicze } & \multicolumn{2}{|r|}{ Typy rolnicze podstawowe } \\
\hline Symbol & Nazwa & Symbol & Nazwa \\
\hline \multirow[t]{2}{*}{1} & \multirow{2}{*}{$\begin{array}{l}\text { Uprawy } \\
\text { polowe }\end{array}$} & 15 & $\begin{array}{l}\text { Specjalizujące się w uprawie zbóż (łącznie z ryżem), roślin } \\
\text { oleistych i wysokobiałkowych na nasiona }\end{array}$ \\
\hline & & 16 & Specjalizujące się w uprawie polowej różnych gatunków roślin \\
\hline \multirow{3}{*}{2} & \multirow{3}{*}{$\begin{array}{l}\text { Uprawy } \\
\text { ogrodni- } \\
\text { cze }\end{array}$} & 21 & $\begin{array}{l}\text { Specjalizujace się w uprawach ogrodniczych (warzyw, } \\
\text { truskawek, kwiatów i roślin ozdobnych) pod wysokimi } \\
\text { osłonami }\end{array}$ \\
\hline & & 22 & $\begin{array}{l}\text { Specjalizujace się w gruntowych uprawach ogrodniczych } \\
\text { (warzyw, truskawek, kwiatów i roślin ozdobnych) }\end{array}$ \\
\hline & & 23 & $\begin{array}{l}\text { Specjalizujace się w uprawie grzybów i w szkółkarstwie oraz } \\
\text { uprawach ogrodniczych (warzyw, truskawek, kwiatów i roślin } \\
\text { ozdobnych) }\end{array}$ \\
\hline 3 & Winnice & 35 & Specjalizujące się w uprawie winorośli \\
\hline \multirow{3}{*}{4} & \multirow{3}{*}{$\begin{array}{l}\text { Uprawy } \\
\text { trwałe }\end{array}$} & 36 & $\begin{array}{l}\text { Specjalizujace się w uprawie drzew i krzewów owocowych } \\
\text { (bez winorośli i oliwek) }\end{array}$ \\
\hline & & 37 & Specjalizujące się w uprawie oliwek \\
\hline & & 38 & $\begin{array}{l}\text { Specjalizujace się w uprawie drzew i krzewów owocowych } \\
\text { (uprawy trwałe) }\end{array}$ \\
\hline 5 & $\begin{array}{l}\text { Krowy } \\
\text { mleczne }\end{array}$ & 45 & Specjalizujące się w chowie bydła mlecznego \\
\hline \multirow{3}{*}{6} & \multirow{3}{*}{$\begin{array}{l}\text { Zwierzęta } \\
\text { trawożer- } \\
\text { ne }\end{array}$} & 46 & Specjalizujące się w chowie bydła rzeźnego (w tym hodowla) \\
\hline & & 47 & $\begin{array}{l}\text { Specjalizujace się w chowie bydła mlecznego i rzeźnego } \\
\text { (w tym hodowla) }\end{array}$ \\
\hline & & 48 & $\begin{array}{l}\text { Specjalizujace się w chowie owiec, kóz i innych zwierząt } \\
\text { żywionych paszami objętościowymi }\end{array}$ \\
\hline \multirow{3}{*}{7} & \multirow{3}{*}{$\begin{array}{l}\text { Zwierzęta } \\
\text { ziarno- } \\
\text { żerne }\end{array}$} & 51 & Specjalizujące się w chowie trzody chlewnej \\
\hline & & 52 & Specjalizujące się w chowie drobiu \\
\hline & & 53 & $\begin{array}{l}\text { Specjalizujące się w chowie zwierząt żywionych paszami } \\
\text { treściwymi }\end{array}$ \\
\hline
\end{tabular}


cd. tabeli 1

\begin{tabular}{|c|c|c|l|}
\hline \multicolumn{2}{|c|}{ Typy rolnicze } & \multicolumn{2}{c|}{ Typy rolnicze podstawowe } \\
\hline Symbol & Nazwa & \multicolumn{2}{|c|}{ Nazwa } \\
\hline \multirow{2}{*}{8} & \multirow{2}{*}{ Mieszane } & 61 & Mieszane - różne uprawy \\
\cline { 3 - 4 } & 74 & $\begin{array}{l}\text { Mieszane - różne zwierzęta, z przewagą zwierząt żywionych } \\
\text { paszami objętościowymi }\end{array}$ \\
\cline { 3 - 4 } & & $\begin{array}{l}\text { Mieszane - różne zwierzęta, z przewagą zwierząt żywionych } \\
\text { paszami treściwymi }\end{array}$ \\
\cline { 3 - 4 } & 83 & $\begin{array}{l}\text { Mieszane - uprawy polowe i zwierzęta żywione paszami ob- } \\
\text { jętościowymi }\end{array}$ \\
\cline { 3 - 4 } & 84 & Mieszane - różne uprawy i zwierzęta \\
\hline
\end{tabular}

Źródło: Wyniki standardowe 2012 uzyskane przez gospodarstwa rolne uczestniczące w polskim FADN.

Do kosztów energii zaliczono następujące kategorie kosztów: materiały opałowe (wegiel, miał, brykiet, drewno, koks, gaz opałowy, olej opałowy), materiały pędne kupowane do baków zbiorników (benzyna, olej, gaz napędowy, inne materiały pędne), materiały pędne kupowane do dużych zbiorników (benzyna, olej napędowy, inne materiały pędne, drewno opałowe), opłaty (energia elektryczna, podgrzanie wody, centralne ogrzewanie).

\section{Wyniki badań i dyskusja}

Okres 2007-2012 to czas bardzo istotnych zmian koniunktury w rolnictwie. Generalnie możemy wyróżnić dwa okresy. Do 2007 roku ceny produktów rolnych (z wyjątkiem wieprzowiny) wzrastały. W latach 2008-2009 nastąpił gwałtowny spadek cen i pogorszenie koniunktury w rolnictwie. W kolejnych latach jednak sytuacja się poprawiła, ale nie osiągnęła takiego poziomu, jak w szczycie 2007 roku [Grzelak 2013]. Jednakże w całym badanym okresie zanotowano stały wzrost kosztów energii we wszystkich typach gospodarstw (z wyjątkiem typy gospodarstwa ogrodnicze) - rysunek 1 .

W celu pokazania tych relacji w sposób jak najbardziej czytelny typ gospodarstwa ogrodnicze przeniesiono na kolejny wykres (rys. 2).

Największe koszty energii bezsprzecznie zanotowano w gospodarstwach ogrodniczych. Były one 3-4-krotnie wyższe niż w drugim pod względem typie uprawy polowe. W 2012 roku wśród pozostałych gospodarstw najwyższe koszty energii poniesiono $\mathrm{w}$ gospodarstwach uprawy polowe (34 611,03 zł), najniższe dla typu uprawy trwałe $(15239,81 \mathrm{zl})$ i zwierzęta trawożerne $(14745,69 \mathrm{zl})$. 


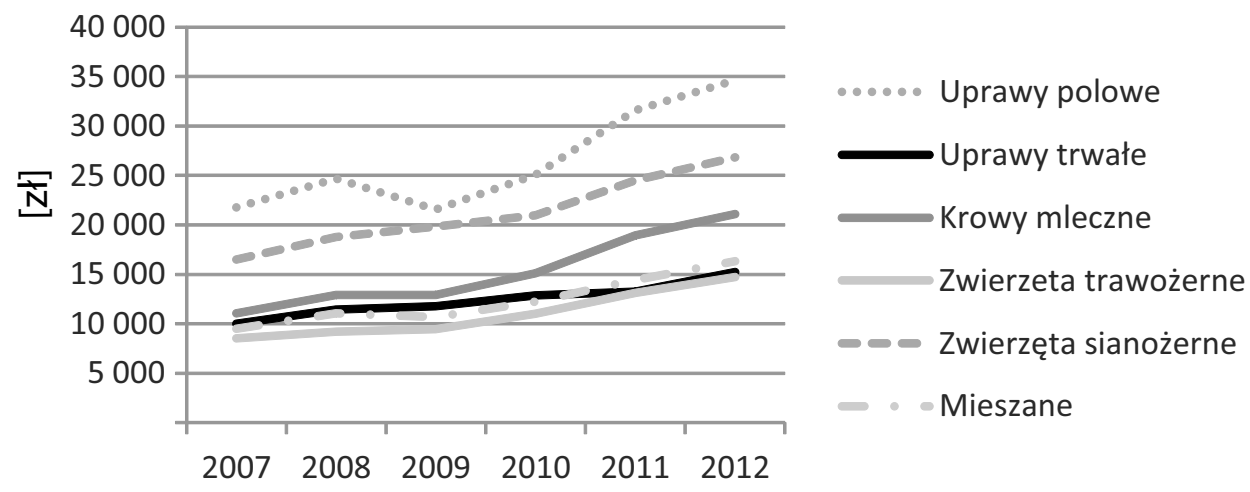

\section{Rysunek 1}

Koszty roczne energii w zależności od typu gospodarstw rolnych

Źródło: Obliczenia własne na podstawie danych FADN.

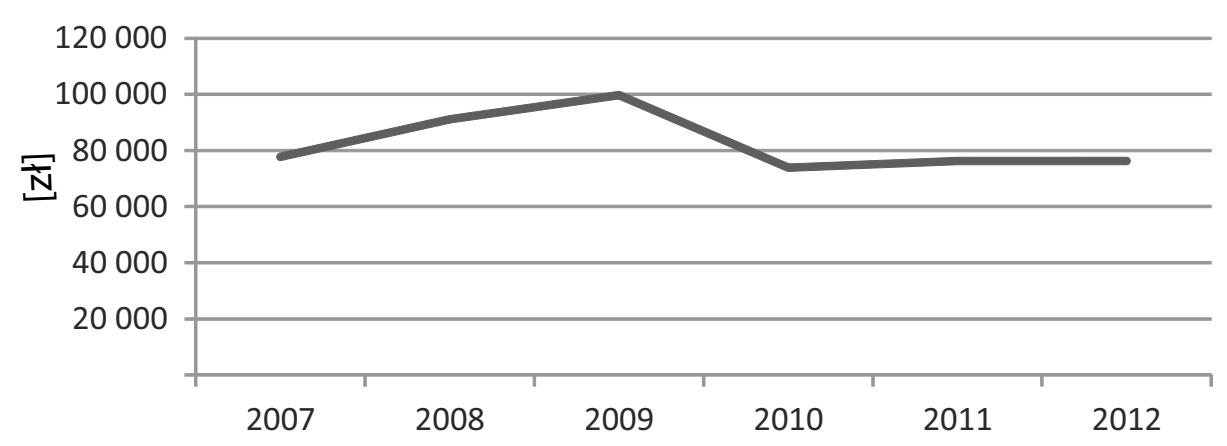

\section{Rysunek 2}

Koszty energii w gospodarstwach ogrodniczych

Źródło: Obliczenia własne na podstawie danych FADN.

Co ciekawe, poziom tych kosztów w gospodarstwach ogrodniczych w badanym okresie podlegał niewielkim wahaniom i w badanym okresie zmniejszył się o 5,36\%. W przypadku pozostałych typów gospodarstw zanotowano znaczący wzrost kosztów energii w szczególności dla typu krowy mleczne $(90,72 \%)$ oraz typu mieszane i zwierzęta trawożerne (nieco ponad 70\%).

Koszty energii warto również odnieść do kosztów ogólnych gospodarstwa. Ponownie wyodrębniono typ uprawy ogrodnicze charakteryzujący się niezwykle wysokim udziałem kosztów energii w kosztach całkowitych. W całym badanym okresie udział ten wzrósł z 28,65\% w 2007 roku do 33,38\% w 2012 roku. 
Oznacza to, że 1/3 wszystkich kosztów w tych gospodarstwach to koszty szeroko rozumianej energii (rys. 3).

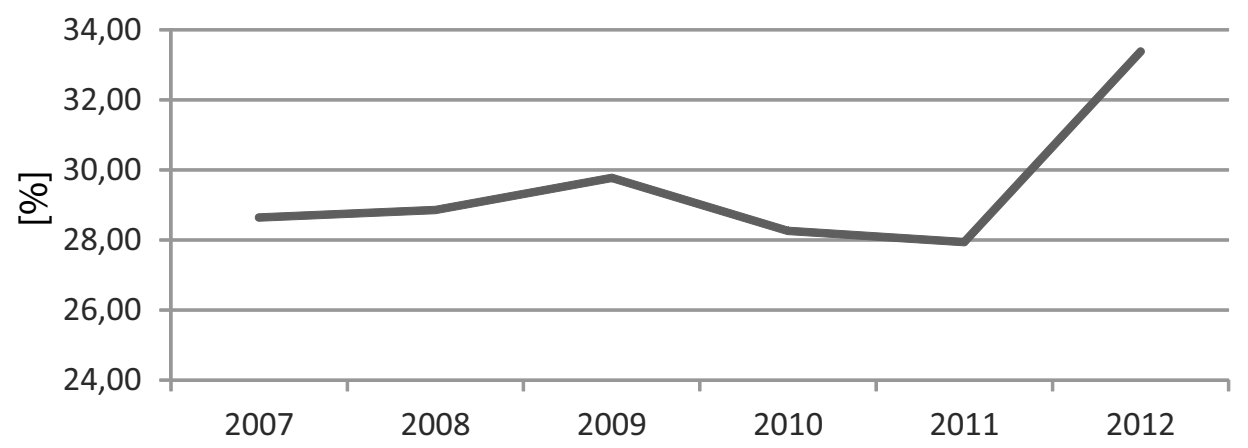

\section{Rysunek 3}

Udział kosztów energii w kosztach ogółem w gospodarstwach ogrodniczych

Źródło: Obliczenia własne na podstawie danych FADN.

W przypadku pozostałych typów upraw obserwacje nie są tak jednoznaczne (rys. 4). Najwyższy udział kosztów energii zanotowano dla upraw polowych. Udział ten wzrósł w badanym okresie z 13,57 do 15,75\%. Podobna sytuacja miała miejsce w przypadku zwierząt ziarnożernych, gdzie wzrost ten był jeszcze gwałtowniejszy - z 6,23\% w 2007 roku do 11,41\% w 2012 roku.
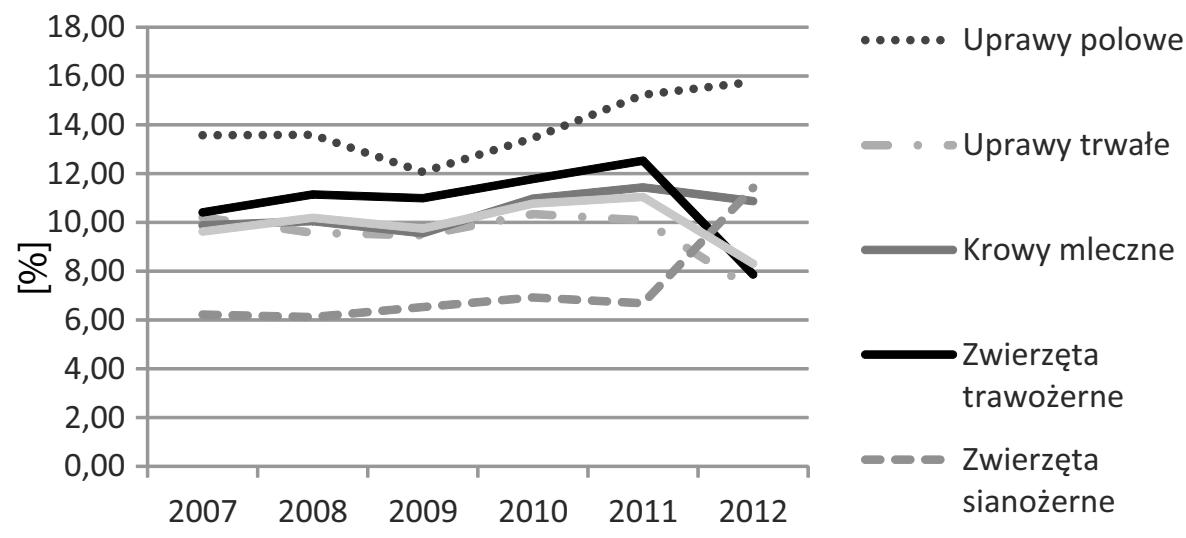

Rysunek 4

Udział kosztów energii w kosztach ogółem

Źródło: Obliczenia własne na podstawie danych FADN. 
Z kolei dla zwierząt trawożernych typu mieszanego, upraw trwałych zanotowano spadek udziału kosztów energii w kosztach ogółem. Największą zmianę odnotowano dla ostatniego typu - z 9,62\% w 2007 roku do 8,31\% w 2012 roku. Dla typu krowy mleczne zmian praktycznie nie zaobserwowano. W latach 2007 -2012 cały czas rosły koszty energii na 1 ha użytków rolnych (tab. 2).

Koszty te są niezwykle wysokie dla upraw ogrodniczych, w 2012 roku wynosiły 10 398,21 zł na 1 ha. Dla pozostałych typów koszty te są kilkunastokrotnie niższe i wahają się od 458,22 zł dla zwierzą trawożernych do 1005,92 zł dla upraw trwałych. W badanym okresie koszty te charakteryzowały się dużą dynamiką wzrostu, szczególnie dla krów mlecznych $(69,38 \%)$ i zwierząt trawożernych $(65,82 \%)$. Nie miało to jednak przełożenia na obciążenie dochodu gospodarstw kosztami energii (rys. 5 i 6). Szczególna sytuacja ponownie miała miejsce w przypadku gospodarstw typu uprawy ogrodnicze. W 2008 roku, aby osiągnąc 1 zł dochodu należało ponieść 1,1 zł kosztów energii. W badanym okresie obciążenie to zmniejszało się, osiagając w 2012 zł wartość 73\%.

Zupełnie inaczej wygląda sytuacja dotycząca obciążeń dochodu pozostałych typów. Widać tutaj zdecydowany wpływ koniunktury w rolnictwie. Szczególne duże wartości zostały osiagnnięte w 2008 i 2009 roku, kiedy miało miejsce załamanie cen produktów rolnych, a co za tym idzie spadek dochodów gospodarstw. Koszty energii w dużym stopniu są kosztami stałymi i nie podlegają szybkim zmianom.

W badanym okresie stwierdzono duże wahania obciążenia dochodu kosztami energii. Dla upraw polowych i krów mlecznych był to wzrost (odpowiednio: z 19,52 do $30,23 \%$ i z 14,09 do $21,43 \%$ ). Z kolei zwierzęta trawożerne i typ mieszany zanotowały spadek (odpowiednio z 19,61 do 16,25\% i z 20,53 do 17,22\%).

\section{Tabela 2}

Zmiana wielkości kosztów energii na 1ha użytków rolnych w latach 2007-2012

\begin{tabular}{|l|c|c|c|}
\hline Wyszczególnienie & $\begin{array}{c}\text { Koszty energii } \\
\text { w 2007 r. na 1 ha }\end{array}$ & $\begin{array}{c}\text { Koszty energii } \\
\text { w 2012 r. na 1 ha }\end{array}$ & Wzrost [\%] \\
\hline Uprawy polowe & 353,74 & 537,25 & 51,88 \\
\hline Uprawy ogrodnicze & 11257,57 & 10398,21 & $-7,63$ \\
\hline Uprawy trwałe & 755,40 & 1005,92 & 33,16 \\
\hline Krowy mleczne & 385,02 & 652,13 & 69,38 \\
\hline Zwierzęta trawożerne & 276,33 & 458,22 & 65,82 \\
\hline Zwierzęta ziarnożerne & 583,42 & 825,12 & 41,43 \\
\hline Mieszane & 359,30 & 549,05 & 52,81 \\
\hline
\end{tabular}

Źródło: Obliczenia własne na podstawie danych FADN. 
52

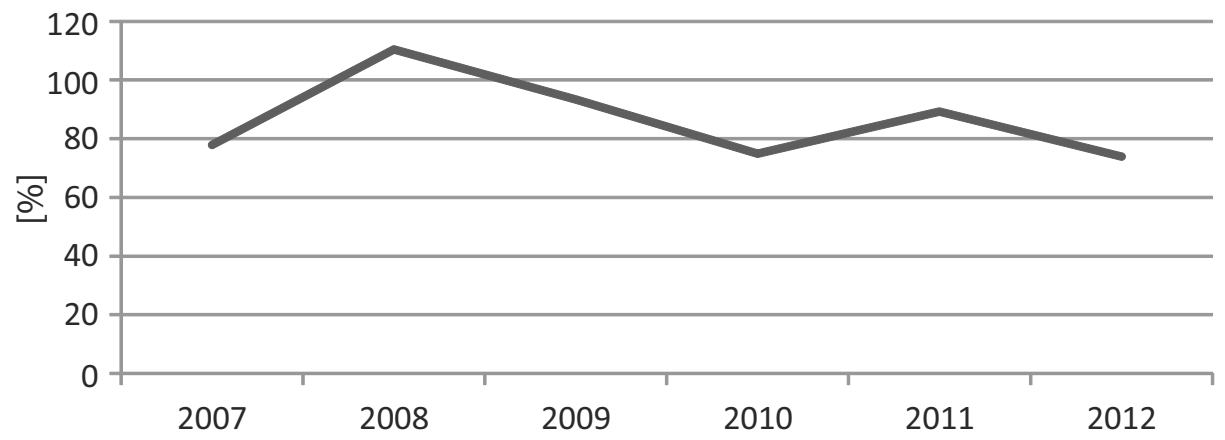

\section{Rysunek 5}

Obciążenie dochodu gospodarstw ogrodniczych kosztami energii

Źródło: Obliczenia własne na podstawie danych FADN.

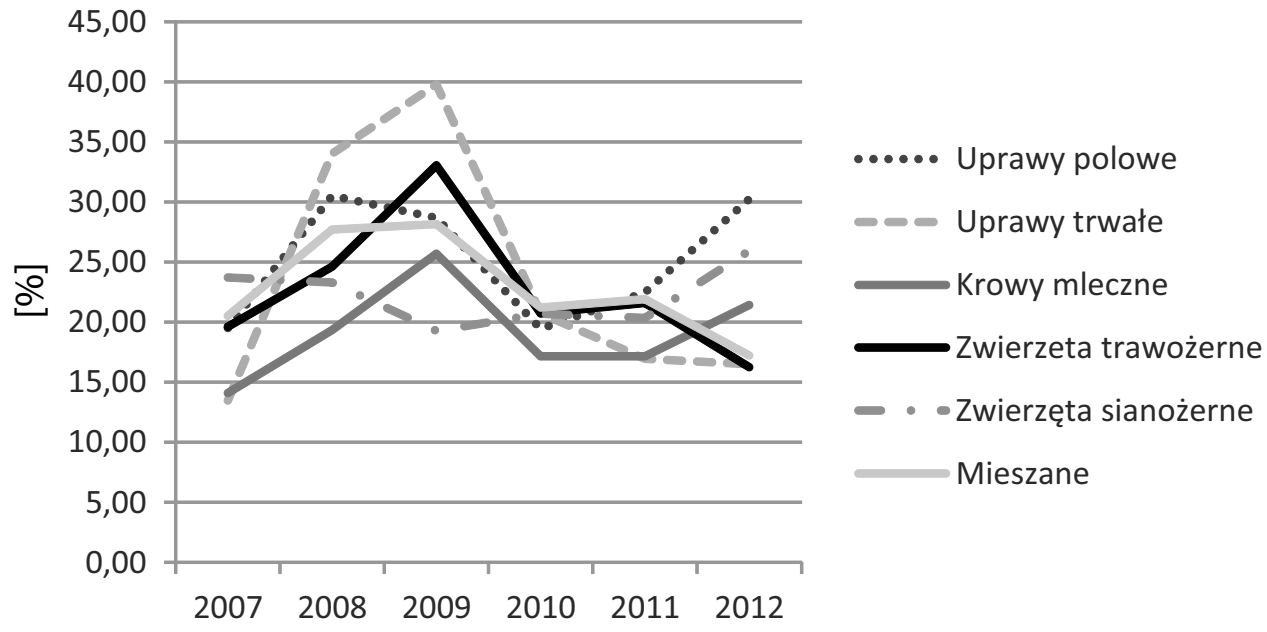

Rysunek 6

Obciążenie dochodu kosztami energii

Źródło: Obliczenia własne na podstawie danych FADN.

\section{Wnioski}

Przeprowadzone badania pozwalają na wyciągnięcie następujących wniosków:

1. Wielkość kosztów energii i udział w kosztach ogólnych są silnie uzależnione od typu rolniczego. 
2. W typie uprawy ogrodnicze koszty energii odgrywają decydującą rolę, ponieważ. Są one na poziomie kilkukrotnie wyższym niż koszy energii w pozostałych typach gospodarstw i stanowią do 33\% wszystkich kosztów gospodarstwa.

3 . W pozostałych typach gospodarstw koszty energii stanowią od $7,24 \%$ kosztów dla typu uprawy trwałe do $15,75 \%$ dla typu uprawy polowe.

4. W badanym okresie zaobserwowano duże wahania obciążenia dochodu gospodarstw kosztami energii uzależnione od koniunktury na rynkach rolnych

W ostatnich latach w świecie rosnących cen energii i kurczących się zasobów coraz większego znaczenia nabierają kwestie kosztów energii w produkcji rolniczej oraz jej efektywnego wykorzystania. Rolnictwo krajów rozwiniętych jest niezwykle mocno uzależnione od tego czynnika produkcji, a wszelkie problemy z dostawami nośników energii będą miały bezpośrednie przełożenie na produkcje wszystkich płodów rolnych.

\section{Literatura}

BOWDEN G., 1985: The social construction of validity in estimates of US crude oil reserves, Social Studies of Science 15, s. 207-240.

CHAPMAN I., 2014: The end of Peak Oil? Why this topic is still relevant despite recent denials, Ian Chapman, Energy Policy 64, s. 93-101.

European Environment Agency, http://www.eea.europa.eu/data-and-maps (data dostępu: 15.03.2014).

FADN: Wyniki standardowe 2012 uzyskane przez gospodarstwa rolne uczestniczące w polskim FADN. Część I, Wyniki standardowe, Warszawa 2013.

GRZELAK A., 2013: Sytuacja ekonomiczna gospodarstw rolnych $w$ warunkach zmian koniunktury gospodarczej (2007-2009), Roczniki Ekonomii Rolnictwa i Rozwoju Obszarów Wiejskich, t. 100, z. 1, Warszawa, s. 78-88.

International Energy Agency, 2012: World Energy Outlook 2012, Synthesis, Paris.

IPCC: Climate change 2013, The Physical Sciences Basis, Summary for Policymakers, IPCC, Switzerland.

MAUGERI L., 2012: Oil: The Next Revolution, Discussion Paper 2012-10, Belfer Center for Science and International Affairs, Harvard Kennedy School, Cambridge, s. 32-39.

PAWLAK J., 2012: Efektywność nakładów energii w rolnictwie polskim, Rocznik Nauk Rolniczych, SERIA G, t. 99, z. 1, s. 121-128. 


\title{
The importance of energy costs depending on the type of farms
}

\begin{abstract}
In the first part of the paper presents economic basis of growing importance of energy costs and consumption in agriculture. The second part based on FADN (Farm Accountancy Data Network) presents importance of energy costs for individual farms in relation to their type. It was revealed that the cost of energy have the greatest significance for the horticulture farms, representing up to $33 \%$ of all costs incurred. In other types of households energy costs represent from $7.24 \%$ of the cost for the permanent crops up to $15.75 \%$ for the filed crops. In the period 2007-2012 there was an increase in the cost of energy in almost all types of households (with the exception of horticulture) both average per farm and per 1 ha of agricultural land.
\end{abstract}

